\title{
RESPON PERTUMBUHAN TANAMAN JAGUNG TERHADAP APLIKASI BIOCHAR PADA LAHAN KERING DENGAN DUA SISTEM IRIGASI
}

\author{
Raden Soedradjad, Sigit Soeparjono \\ Program Studi Agronomi, Fakultas Pertanian, Universitas Jember \\ Jl. Kalimantan No. 37 Jember \\ email : soedradjad.faperta@unej.ac.id
}

Submitted:12 Januari 2022, Accepted:22 Januari 2022, Approved:27 Januari 2022

\begin{abstract}
ABSTRAK
Indonesia memiliki lahan kering seluas 144,47 juta hektar dan $76 \%$ diantaranya berada di dataran rendah $(<700 \mathrm{mdpl})$, serta berpotensi untuk ditanami tanaman pangan. Pengembangan lahan kering dapat dilakukan melalui penerapan rekayasa biologi tanah dan pengelolaan air untuk mendukung keberlanjutan agroekosistem. Biochar dalam tanah akan menyediakan tempat hidup dan sumber energi bagi mikroorganisme. Sedangkan air berperan dalam pemenuhan kebutuhan mikroorganisme dan tumbuhan. Percobaan dilakukan di Desa Kandang, Kecamatan Kapongan, Situbondo pada musim kemarau 2020. Perlakuan aplikasi biochar terdiri atas $1.000 \mathrm{~kg}$ Biochar per hektar dan $(200 \mathrm{~kg}$ biochar $+800 \mathrm{~kg}$ biochar kompos) per hektar; sedangkan sistem irigasi terdiri atas irigasi permukaan

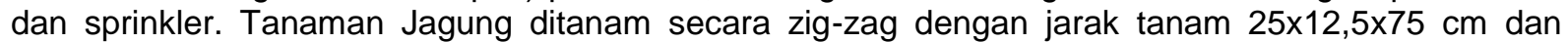
dalam satu lubang diisi satu biji. Variabel percobaan yang diamati meliputi laju pertumbuhan relatif $\left(\mathrm{g} /\right.$ hari), kadar klorofil daun $\left(\mu \mathrm{mol} / \mathrm{m}^{2}\right)$, tinggi tanaman $(\mathrm{cm})$, dan berat kering tanaman $(\mathrm{g})$. Efek menguntungkan dari aplikasi Biochar dalam kondisi air terbatas adalah meningkatnya Water Holding Capacity (WHC) dan aktivitas mikroorganisme. Dengan demikian, tanaman Jagung akan mampu menyerap air dan nutrisi secara optimal dan tanaman Jagung tumbuh lebih baik. Hasil penelitian menyimpulkan bahwa aplikasi Biochar dan sistem irigasi berpengaruh nyata terhadap pertumbuhan Tanaman Jagung di Lahan Kering.
\end{abstract}

Kata kunci: biochar, kompos, jagung, irigasi.

\section{ABSTRACT}

Indonesia has 144.47 million hectares of dry land and $76 \%$ of them are in the lowlands (<700 masl), and have the potential to be planted with food crops. Dry land development can be done through the application of soil biological engineering and water management to support the sustainability of agroecosystems. Biochar in the soil will provide a place to live and a source of energy for microorganisms, while water will fulfill the needs of microorganisms and plants. The experiment was carried out in Kandang Village, Kapongan District, Situbondo during the dry season of 2020. The biochar application treatment consisted of $1,000 \mathrm{~kg}$ of biochar per hectare and $(200 \mathrm{~kg}$ biochar +800 $\mathrm{kg}$ biochar compost) per hectare; while the irrigation system consists of surface irrigation and sprinklers. Corn plants are planted in a zigzag manner with a spacing of $25 \times 12.5 \times 75 \mathrm{~cm}$ and one seed is planted in each hole. Experimental variables observed included relative growth rate or RGR (g.day $\left.{ }^{1}\right)$, leaf chlorophyll content $\left(\mu \mathrm{mol} / \mathrm{m}^{2}\right)$, plant height $(\mathrm{cm})$, and plant dry weight $(\mathrm{g})$. The beneficial effect of the application of Biochar in limited water conditions is an increase in the Water Holding Capacity (WHC) and the activity of microorganisms. Thus, corn plants will be able to absorb water and nutrients optimally and corn plants will grow better. The results showed that the application of Biochar and irrigation systems has a significantly effected the growth of corn plants on dry land.

Keywords: biochar, compost, corn, irrigation.

\section{PENDAHULUAN}

Ahli pertanian mendefinisikan lahan kering dengan sudut pandang yang berbeda. Berdasarkan jumlah mutlak curah hujan, Convention to Combat Desertification mendefinisikan lahan kering sebagai daerah dengan curah hujan antara 0 dan $600 \mathrm{~mm}$ per tahun, tergantung pada ketinggian dan garis lintang. Berdasarkan panjang musim hujan dan suhu, didefinisikan sebagai daerah dengan kelembaban yang cukup untuk mendukung pertumbuhan tanaman kurang dari tiga bulan, dengan suhu rata-rata minimal $27^{\circ}$ Celcius. Definisi lahan kering masih berbeda 
antara satu peneliti dengan peneliti lain, antara satu wilayah dan wilayah lain.

Lahan kering, dalam makalah ini diartikan sebagai sebidang lahan dengan keterbatasan sumber air sepanjang tahun dan tidak pernah dalam kondisi tergenang. Keterbatasan sumber air berarti kandungan lengasnya (soil moisture content) selalu berada di bawah kadar air kapasitas lapangan. Jumlah curah hujan pada saat musim hujan yang tidak dapat mengimbangi kebutuhan air sepanjang tahun, terutama untuk kebutuhan evaporasi dan transpirasi tanaman.

Luas lahan kering di Indonesia mencapai 144,47 juta ha $(76 \%$ dari luas daratan Indonesia) dan 111,3 juta ha (76\% dari luas lahan kering) berada di dataran rendah (< $700 \mathrm{~m} \mathrm{dpl)} \mathrm{(Mulyani,} \mathrm{2021).} \mathrm{Lahan}$ kering tersebut merupakan lahan yang berpotensi ditanami berbagai jenis tanaman pangan, sayuran, perkebunan serta penggembalaan ternak (Ritung, dkk., 2015). Lahan kering di dataran rendah, memiliki curah hujan dibawah $2.000 \mathrm{~mm} / \mathrm{tahun}$ dan produktivitasnya rendah sampai sangat rendah (Niemeijer, et.al., 2005; Magray, et.al, 2014). Jagung merupakan komoditas tanaman pangan penting bagi Indonesia setelah Padi. Biji jagung, sebagian besar ( \pm $51 \%)$ digunakan sebagai bahan baku pakan ternak, selanjutnya $\pm 41 \%$ digunakan untuk bahan pangan dan sisanya untuk benih dan hasil yang hilang. Petani di Indonesia, sebagian besar $( \pm 71,40 \%)$ menanam tanaman Jagung secara monokultur di lahan bukan sawah atau lahan kering (BPS, 2021). Kendala penanaman Jagung di lahan kering, diantaranya (1) ketersediaan air tanah rendah, sehingga hanya sedikit jenis tanaman yang mampu beradaptasi, (2) produksi biomasa rendah, sehingga kadar bahan organik tanah rendah yang menyebabkan kesehatan tanah juga rendah, dan (3) suhu udara di atas suhu rata-rata sehingga evapotranspirasi tinggi serta konsentrasi $\mathrm{O}_{2}$ lebih tinggi daripada konsentrasi $\mathrm{CO}_{2}$ yang mengakibatkan terjadinya proses fotorespirasi (Arnon, 1992; Creswell and Martin, 1998; IIRR, 2014; Magero, 2019).

Tanaman Jagung yang ditanam di lahan kering akan mengalami cekaman air. Cekaman air mempengaruhi hampir setiap aspek pertumbuhan dan perkembangan tanaman serta mempengaruhi anatomi, morfologi, fisiologi dan biokimia tanaman tanaman (Arnon, 1992). Produktivitas tanaman jagung rata-rata di lahan kering hanya 4,11 t/ha biji kering; sedangkan potensi hasil mencapai 12 t/ha dengan produktivitas rata- rata 9,1 ton per hektar (Adnan, dkk., 2010). Defisit air terjadi pada tanaman setiap kali transpirasi melebihi penyerapan air. Hal ini disebabkan tanaman kehilangan air secara berlebihan tetapi penyerapan dari tanah berkurang, atau keduanya (Arnon, 1992). Air sangat penting untuk pertumbuhan tanaman, karena tanpa air semua tanaman tidak akan mungkin mengalami pertumbuhan karena air berperanan dalam fotosintesis maupun translokasi fotosintat (Bista, et.al., 2019).

Air yang ditambahkan melalui teknik irigasi di lahan kering perlu mempertimbangkan kondisi curah hujan yang terbatas (Ali, 2010). Teknik irigasi yang umum diterapkan oleh petani adalah surface irrigation (irigasi permukaan). Irigasi permukaan walaupun mudah diaplikasikan dan murah, tetapi akan banyak kehilangan air, mudah terjadinya erosi dan tidak dapat diaplikasikan pada lahan yang mempunyai kemiringan diatas 20 persen. Teknik irigasi yang dapat menyediakan air secara efisien dan dapat mempertahankan rezim kelembaban tanah dan udara adalah irigasi sprinkler atau irigasi pancar (Biswas, 2015).

Keuntungan irigasi sprinkler daripada irigasi permukaan adalah cocok untuk semua jenis tanah dengan laju infiltrasi kurang dari 4 $\mathrm{cm} / \mathrm{jam}$, cocok untuk semua tanaman, cocok untuk lahan yang tidak rata, saluran pasokan air dan pematang tidak diperlukan, menghemat air dan tenaga kerja, mendukung pertumbuhan tanaman dan mengurangi serangan organisme pengganggu tanaman. Namun, irigasi sprinkler juga mempunyai kekurangan, diantaranya angin akan mendistorsi pola sprinkler dan menyebabkan distribusi air tidak merata, pemasakan tongkol jagung yang masih muda perlu dilindungi dari dampak semprotan, dan biaya awal relatif lebih tinggi daripada irigasi permukaan.

Budidaya tanaman Jagung di lahan kering dapat dilakukan dengan berbagai teknologi, diantaranya (1) teknologi pengelolaan air terpadu, seperti irigasi permukaan, tetes, pancar, dan lain-lain, (2) teknologi pengelolaan tanah untuk perbaikan kualitas tanah, seperti aplikasi kompos, biochar, dan lain-lain, serta (3) pengembangan integrasi tanaman dan ternak, rotasi, budidaya lorong, dan agroforestri (Umrani and Jain, 2010; Suryani, dkk., 2020). Namun, masih jarang kajian peningkatan produktivitas lahan kering dengan pendekatan proses agroekosistem dengan tujuan untuk melindungi keberlanjutan sumberdaya lahan kering (Lichtfouse, et.al., 2011). Pendekatan proses agroekosistem bertumpu pada 
kesehatan tanah, dimana peran utama dimainkan oleh mikroorganisme yang tergantung kepada kandungan C-organik tanah sebagai tempat hidup dan sumber energinya, misalnya dengan aplikasi kompos dan Biochar.

Pada lahan kering, umumnya kompos diaplikasikan dalam jumlah besar untuk meningkatkan $\mathrm{C} / \mathrm{N}$ rasio tanah. Hal ini akan menyebabkan suhu tanah meningkat dan menyebabkan akumulasi logam berat $(\mathrm{Cu}, \mathrm{Pb}$, Zn, dll) di dalam tanah (Tsai, et al., 2019). Beberapa kajian menunjukan bahwa Biochar mampu berperan meningkatkan kesuburan tanah; dimana Biochar menjadi tempat hidup dan sumber bagi mikroorganisme serta mampu meningkatkan water holding capacity tanah, sehingga De-la-Rosa (2020) merekomendasi aplikasi Biochar sebagai amandemen tanah di lahan kering.

Aplikasi biochar, menurut Duarte, et al. (2019) bertujuan untuk memperbaiki sifat fisik, kimia dan hidrologi tanah, karena partikel biochar yang lebih kecil meningkatkan distribusi ukuran pori makro, porisitas tanah serta kandungan karbon total terutama di tanah berpasir. Hasil penelitian Bista, et al (2019) menyimpulkan bahwa Biochar dapat meningkatkan kesehatan tanah dan produktivitas tanaman. Aplikasi biochar juga dapat meningkatkan bahan organik tanah, $\mathrm{pH}$ tanah, kandungan fosfor $(\mathrm{P})$, kalium $(\mathrm{K})$, kandungan belerang (S) tersedia, serta meningkatkan biomassa pucuk dan akar tanaman gandum.

Di lahan kering tropis yang cuacanya tinggi, aplikasi pupuk organik dan biochar dapat meningkatkan cadangan nutrisi di zona perakaran tanaman, mengurangi pencucian nutrisi, dan dengan demikian meningkatkan produksi tanaman (Tsai, et.al., 2019). Biochar dapat menjadi pasokan/input kunci dalam meningkatkan dan mempertahankan produksi dan sekaligus mengurangi polusi dan ketergantungan pada pupuk anorganik, serta dapat meningkatkan kelembaban tanah dan simpanan karbon. Beberapa studi aplikasi Biochar, terutama berfokus pada efek penambahan Biochar murni atau pupuk buatan; namun, Biochar murni tidak memberikan nutrisi dalam jumlah tinggi. Penggabungan Biochar-Kompos ke dalam tanah dianggap sebagai pendekatan yang menjanjikan untuk mendukung pertumbuhan tanaman (Duarte, et al., 2019).

Berdasarkan alasan di atas, maka dapat dihipotesiskan bahwa penambahan biochar dapat mengurangi jumlah kompos yang ditambahkan ke dalam tanah dan irigasi yang diaplikasikan mampu meningkatkan WHC tanah. Dengan demikian, tanaman mampu tumbuh secara optimal karena bahan organik tanah lebih stabil, mineralisasi Corganik tanah berkurang, dan status nutrisi tanah meningkat.

Tujuan dari penelitian yang dilakukan adalah untuk melihat pengaruh jumlah penambahan biochar dan perbedaan teknik irigasi terhadap pertumbuhan tanaman jagung di lahan kering.

\section{METODOLOGI PENELITIAN}

Percobaan dilakukan di Desa Kandang, Kecamatan Kapongan, Kabupaten Situbondo (Gambar 1) yang tanahnya bertekstur silt loam soil yang diambil pada kedalamam sampai $30 \mathrm{~cm}$. Lahan percobaan berada pada koordinat $-7^{0} 74^{\prime} 84^{\prime \prime}$ LS dan $114^{\circ}$ 06'28" BT dengan ketinggian 20 - 35 m diatas permukaan laut. Percobaan dirancang dengan menggunakan rancangan acak kelompok yang terdiri atas 2 (dua) perlakukan yaitu dosis biochar dan sistem irigasi. Dosis Biochar terdiri atas $1.000 \mathrm{~kg}$ Biochar/ha (100\% Biochar/ha) dan (200 kg biochar $+800 \mathrm{~kg} \mathrm{kompos}) / \mathrm{ha}$ atau (20\% Biochar $+80 \%$ Kompos)/ha. Teknik irigasi terdiri atas irigasi permukaan dan irigasi sprinkler. Setiap kombinasi perlakuan diulang sebanyak 10 kali. Alat yang digunakan untuk aplikasi irigasi sprinkler adalah big gun sprinkler.

Tanaman Jagung yang digunakan adalah varietas $\mathrm{BISI}-18$ dengan pertimbangan varietas tersebut dapat ditanam di dataran rendah pada musim kemarau dimana lahan kering sangat kekurangan air, keluarnya rambut akar cepat ( \pm 57 hari), dan umur masak fisiologis sekitar 100 hari setelah tanaman. Tanaman jagung ditanam secara

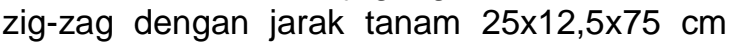
dan dalam satu lubang diisi satu biji. Pupuk yang diberikan adalah $250 \mathrm{~kg}$ urea/ha dan 300 kg phonska/ha. 


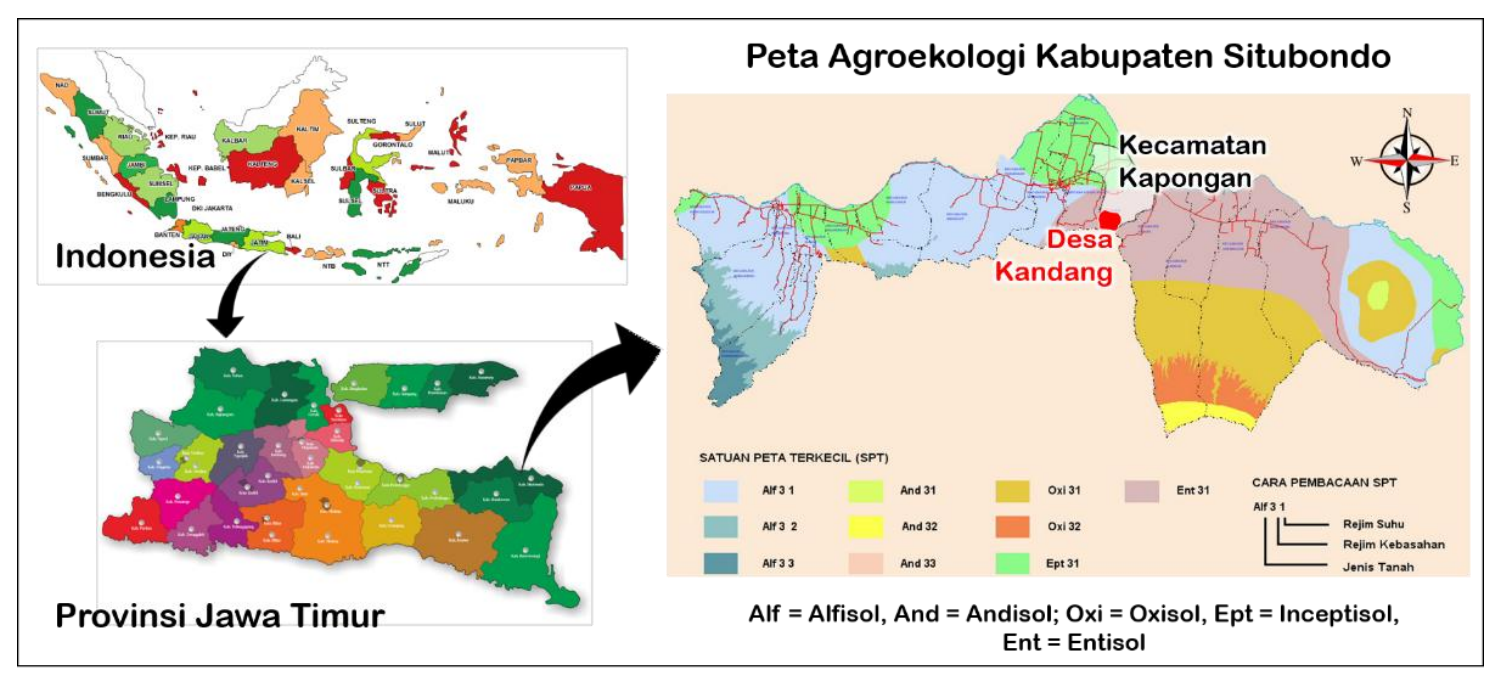

Gambar 1. Peta Lokasi Penelitian (lingkaran merah)

Variabel percobaan yang diamati meliputi laju pertumbuhan relatif ( $\mathrm{g} /$ hari), tinggi tanaman $(\mathrm{cm})$, kadar klorofil daun $\left(\mu \mathrm{mol} / \mathrm{m}^{2}\right)$, dan berat kering tanaman (g). Variabel tersebut diukur dengan menggunakan alat, antara lain oven untuk mengukur berat kering tanaman, dan klorofil-meter SPAD-502 untuk mengukur kadar klorofil daun jagung pada menjelang akhir fase generatif.

Laju Pertumbuhan Relatif (RGR, Relative Growth Rate) tanaman diukur dengan rumus:

$$
R G R=\frac{\overline{\ln \left(W_{2}\right)}-\overline{\ln \left(W_{1}\right)}}{t_{2}-t_{1}}
$$

dimana: $\overline{\ln (W)_{t}}=$ berat kering tanaman ratarata yang ditransformasikan ke In pada waktu $t$ (Hoffmann and Poorter, 2002), dan berat kering tanaman diukur saat tanaman berumur 40 HST dan 60 HST; sedangkan kadar klorofil daun diukur dengan rumus berikut:

$$
C h l=10^{\left.M^{\wedge} 0,265\right)}\left(\mu \mathrm{mol} / \mathrm{m}^{2}\right)
$$

dimana: $C h l=$ kadar klorofil daun $\left(\mu \mathrm{mol} / \mathrm{m}^{2}\right)$ dan $\mathrm{M}=$ angka yang terbaca dalam SPAD-502 (Markell, et al., 1995).

Analisis statistik kinerja dari perlakuan menggunakan Analisis Sidik Ragam (atau Analysis of Varian, ANOVA) dari data berdasarkan Rancangan Acak Kelompok. Berdasarkan nilai Least Significant Difference (LSD), perbedaan perlakuan dibandingkan pada tingkat signifikansi $p<0,05$.

\section{HASIL DAN PEMBAHASAN}

Hasil penelitian disajikan dalam Tabel 1 yang menyajikan sifat tanah di lokasi penelitian. Sedangkan hasil pengamatan variable pertumbuhan disajikan dalam Gambar 2 sampai Gambar 5, yang secara berurutan menyajikan hasil analisis Laju Pertumbuhan Relatif (LPR) tanaman, kadar klorofil daun tanaman Jagung, tinggi tanaman jagung, dan berat kering tanaman. Secara umum, LPR tanaman dipengaruhi oleh serapan air dan untur hara dari tanah oleh tanaman. Serapan hara, khususnya Nitrogen, diwakili dari pengamatan kadar klorofil daun; dimana klorofil daun akan menangkap cahaya tampak untuk fotosintesis yang hasilnya dapat diamati dari variebel pertumbuhan tinggi dan berat kering tanaman.

Tabel 1 memperlihatkan bahwa tanah di lokasi penelitian termasuk tanah berat karena mempunyai tekstur lempung berdebu, sehingga porositas tanah rendah sehingga ketersediaan air tanah yang dapat diserap oleh tanaman juga rendah. Selain itu, kandungan C-organik tanah rendah sehingga diduga populasi mikroorganisme (MO) juga rendah karena C-organik merupakan sumber energi bagi MO. Kandungan Nitrogen $(\mathrm{N})$ tanah tanah sangat rendah sehingga akan mengganggu pertumbuhan vegetatif tanaman karena $\mathrm{N}$ merupakan unsur penyusun klorofil sebagai organel kloroplas yang dapat menyerap cahaya tampak untuk proses fotosintasis; sedangkan air tersedia juga rendah sehingga translokasi fotosintat juga lambat sehingga pertumbuhan tanaman tidak optimal. Kemasaman $(\mathrm{pH})$ tanah sangat basa, sehingga penambahan Biochar dan/atau kompos mampu menurunkan $\mathrm{pH}$ sehingga Kapasitas Tukar Kation (KTK) tanah meningkat dan unsur hara yang tinggi, seperti $\mathrm{P}, \mathrm{K}, \mathrm{Ca}$ dan $\mathrm{Mg}$ dapat diserap tanaman. 
Tabel 1. Sifat Tanah Lokasi Penelitian

\begin{tabular}{lccc}
\hline \multicolumn{1}{c}{ Karakteristik } & Unit & Kadar & Status \\
\hline $\mathrm{C}$ & $\%$ & 1,15 & rendah \\
$\mathrm{N}$ & $\%$ & 0,06 & sangat rendah \\
$\mathrm{C} / \mathrm{N}$ ratio & & 19,17 & tinggi \\
$\mathrm{pH}$ & $\mathrm{cmol} / \mathrm{kg}$ & 9,6 & sangat basa \\
$\mathrm{Kapasitas}$ Tukar Kation & $\mathrm{ppm}$ & 14,5 & rendah \\
$\mathrm{P} 2 \mathrm{O} 5(\mathrm{Olsen}$ method) & $\mathrm{mg} / 100 \mathrm{~g}$ & 39,02 & sangat tinggi \\
$\mathrm{K} 2 \mathrm{O}(\mathrm{HCl} 25 \%)$ & $\mathrm{cmol} / \mathrm{kg}$ & 47,68 & tinggi \\
$\mathrm{Ca}$ & $\mathrm{cmol} / \mathrm{kg}$ & 9,75 & tinggi \\
$\mathrm{Mg}$ & $\%$ & 9,06 & sangat tinggi \\
$\mathrm{Liat}$ & $\%$ & 18 & \\
Lempung & $\%$ & 70 & lempung berdebu \\
Pasir & $\mathrm{v} \%$ & 12 & \\
Porositas & $\mathrm{v} \%$ & 42 & kurang baik \\
Kapasitas Lapang & $\mathrm{v} \%$ & 31 & \\
Titik Layu Permanen & & 11 & \\
\hline
\end{tabular}

Sumber: Data Primer (2020)

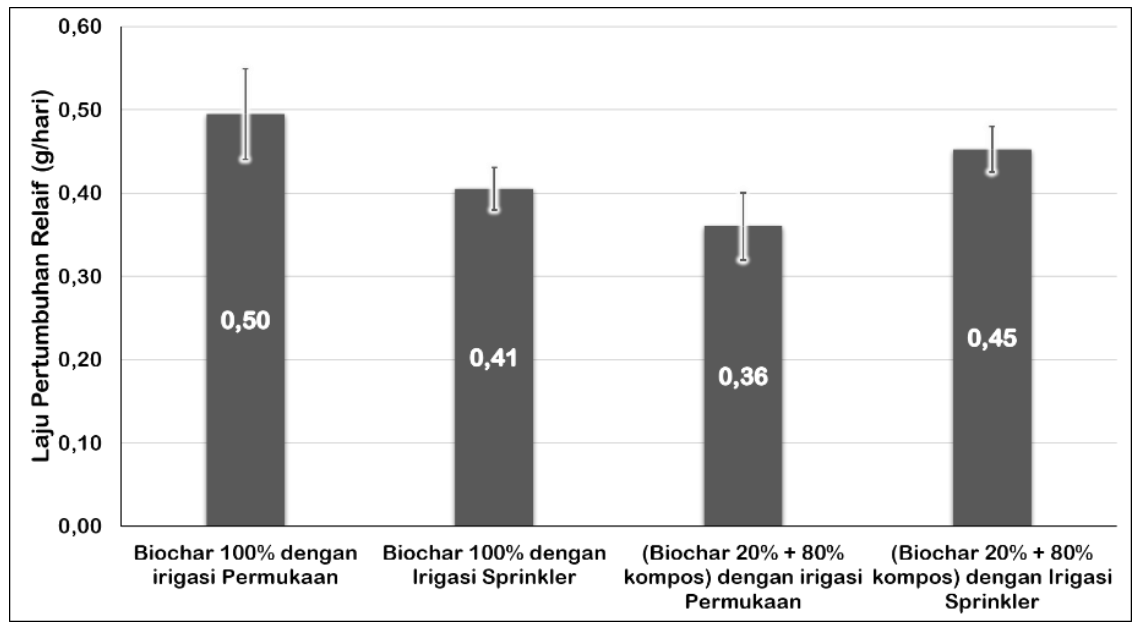

Gambar 2. Laju Pertumbuhan Relatif Tanaman Jagung

Gambar 2 memperlihatkan bahwa aplikasi biochar $100 \%$ pada lahan kering yang diairi melalui irigasi permukaan mempunyai dampak terbaik terhadap Laju Pertumbuhan Relatif (LPR) tanaman Jagung. Aplikasi (100\% Biochar dengan irigasi permukaan), LPR tanaman jagung lebih tinggi $22 \%$ daripada aplikasi $\quad(100 \%$ Biochar dengan irigasi sprinkler). Hal ini menunjukkan bahwa Biochar mampu menahan lebih banyak air pada irigasi permukaan karena air lebih banyak meresap ke dalam tanah. Sedangkan irigasi sprinkler air yang sampai ke tanah relatif lebih sedikit daripada irigasi permukaan. Air yang dipancarkan irigasi sprinkler sebagian terdistorsi oleh angin sehingga air yang sampai ke tanah jumlahnya lebih sedikit daripada irigasi permukaan. Dengan demikian WHC pada lahan kering yang diaplikasi $100 \%$
Biochar dengan irigasi permukaan lebih tinggi dan AWC-nya juga meningkat sehingga serapan air dan hara juga menjadi lebih tinggi.

Laju pertumbuhan relatif tanaman pada aplikasi $100 \%$ Biochar dengan irigasi permukaan lebih tinggi 39\% daripada aplikasi (20\% Biochar $+80 \%$ kompos dengan irigasi permukaan). Maksimum WHC dari aplikasi $100 \%$ Biochar mencapai 46,18\% (hasil pengukuran) lebih tinggi daripada aplikasi (20\% Biochar + $80 \%$ Kompos) yang 43,78 persen. Hal ini dikarenakan ruang pori Biochar lebih banyak daripada Kompos, sehingga luas permukaan yang mampu menahan air pada Biochar lebih luas daripada kompos. Dengan demikian, aplikasi (20\% Biochar + $80 \%$ Kompos) kurang mampu meningkatkan WHC tanah. Efeknya berbeda pada aplikasi $(20 \%$ Biochar $+80 \%$ kompos dengan irigasi 
sprinkler), dimana sistem irigasi ini mampu memanipulasi suhu dan kelembaban udara sehingga evapotranspirasi lebih rendah sehingga serapan air dan hara oleh tanaman menjadi optimal dan LPR menjadi meningkat dan berbeda tidak nyata dengan aplikasi $(20 \%$ Biochar $+80 \%$ Kompos).

Laju pertumbuhan relatif tanaman pada aplikasi $100 \%$ Biochar dengan irigasi permukaan lebih tinggi daripada perlakuan lain diduga serapan air dan hara lebih optimal. Biochar mempunyai ruang pori lebih banyak dan lebih luas sehingga ruang pori dapat digunakan untuk berkembangnya MO. Populasi MO yang lebih banyak berdampak terhadap proses mineralisasi hara dalam tanah menjadi lebih lancar karena KTK tanah meningkat, sehingga serapan hara oleh tanaman menjadi optimal. Hal ini dapat dilihat dari hasil pengamatan kadar klorofil daun (Gambar 3) pada perlakuan 100\% Biochar dengan irigasi permukaan nilainya lebih tinggi daripada perlakuan lain. Klorofil tersusun dari unsur Karbon (C), Magnesium (Mg) dan Nitrogen $(\mathrm{N})$, dimana semakin tinggi kadar klorofil pada daun Jagung menunjukkan bahwa serapan, terutama $\mathrm{N}$ dan $\mathrm{Mg}$, juga tinggi. Aktivitas mikroorganisme yang meningkat mengakibatkan proses mineralisasi nutrisi juga meningkat. Ruang pori tanah dan oksigen dalam tanah yang meningkat merupakan faktor pendorong meningkatnya aktivitas mikroorganime tanah dan proses mineralisasi. Dengan demikian, serapan hara meningkat dan laju pertumbuhan relatif tanaman jagung juga meningkat.

Serapan hara yang meningkat karena aplikasi Biochar juga ditunjukkan oleh hasil penelitian Zulfita, dkk (2020) yang menyimpulkan bahwa serapan hara $(\mathrm{N}, \mathrm{P}, \mathrm{K})$ naik pada aplikasi Biochar sekam padi sebanyak 10 t/ha dengan pemupukan NPK $200 \mathrm{~kg} / \mathrm{ha}$ atau $50 \%$ dari dosis anjuran pada media tanah gambut. Aktivitas mikroorganisme yang meningkat juga ditunjukkan oleh penelitian Belit, dkk (2020) yang menyimpulkan bahwa aplikasi biochar dan mikroorganisme lokal sebanyak $200 \mathrm{cc} / \mathrm{L}$ air mampu meningkatkan tinggi tanaman bibit pisang paling besar.

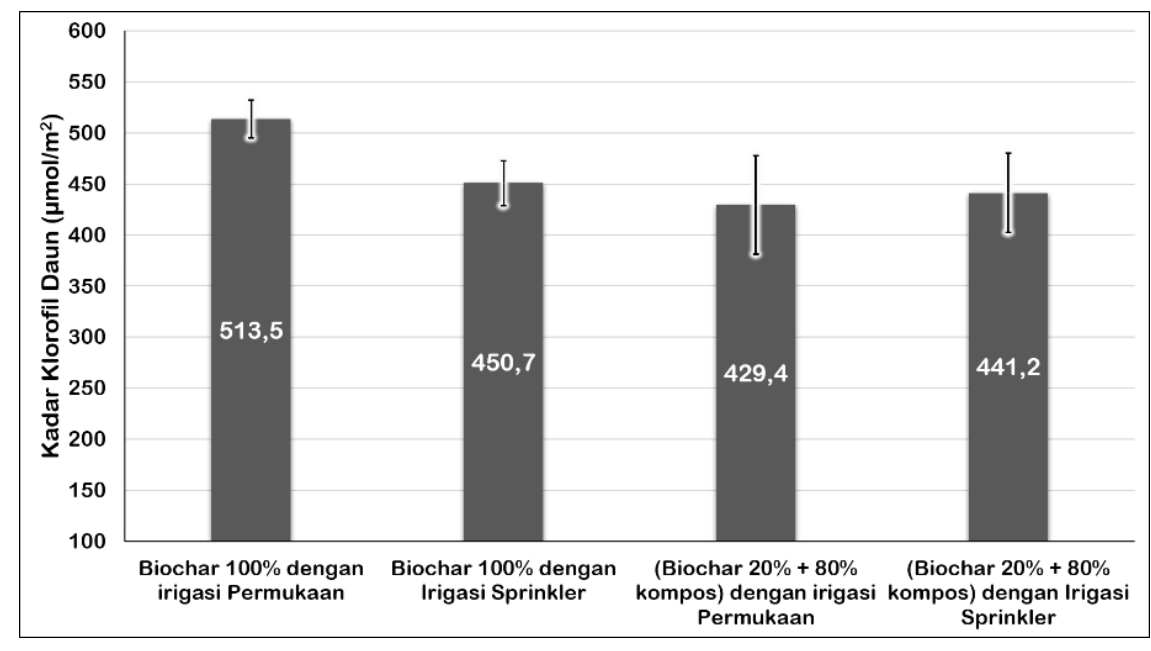

Gambar 3. Kadar Klorofil Daun Tanaman Jagung

Kadar klorofil daun Tanaman Jagung yang lebih tinggi berdampak pada laju fotosintesis tanaman yang lebih tinggi; sedangkan serapan air yang optimal berdampak pada proses translokasi fotosintat ke organ-organ tanaman juga berjalan secara optimal. Oleh karena itu, pertumbuhan tinggi tanaman Jagung pada aplikasi 100\% Biochar dengan irigasi permukaan juga paling tinggi (Gambar 4). Pertumbuhan tinggi tanaman yang baik menunjukkan bahwa proses fotosintesis dan respirasi berlangsung seimbang, sehingga tanaman mengalami pertumbuhan. Pertumbuhan tanaman Jagung dapat diduga melalui berat keringnya, dimana pada aplikasi $100 \%$ Biochar dengan irigasi permukaan menghasilkan berat kering tertinggi dan berbeda nyata dengan perlakuan lain (Gambar 5).

Hal ini dapat dijelaskan bahwa Biochar meningkatkan sifat fisik tanah dalam kondisi drought stress di lahan kering. Biochar memiliki fitur yang dapat meningkatkan sifat tanah seperti kepadatan, keasaman, dan kelembaban/lengas tanah. Sifat fisikokimia tanah yang ditingkatkan dengan aplikasi 
Biochar dan peningkatan kelimpahan dan keragaman mikroorganisme telah berkontribusi pada kemampuan Biochar untuk meningkatkan laju pertumbuhannya, terutama pada fase vegetatif. Porositas tanah yang meningkat dan kepadatan tanah yang menurun, proporsi udara dalam tanah juga membaik, maka akan terjadi peningkatan retensi air tersedia bagi tanaman.

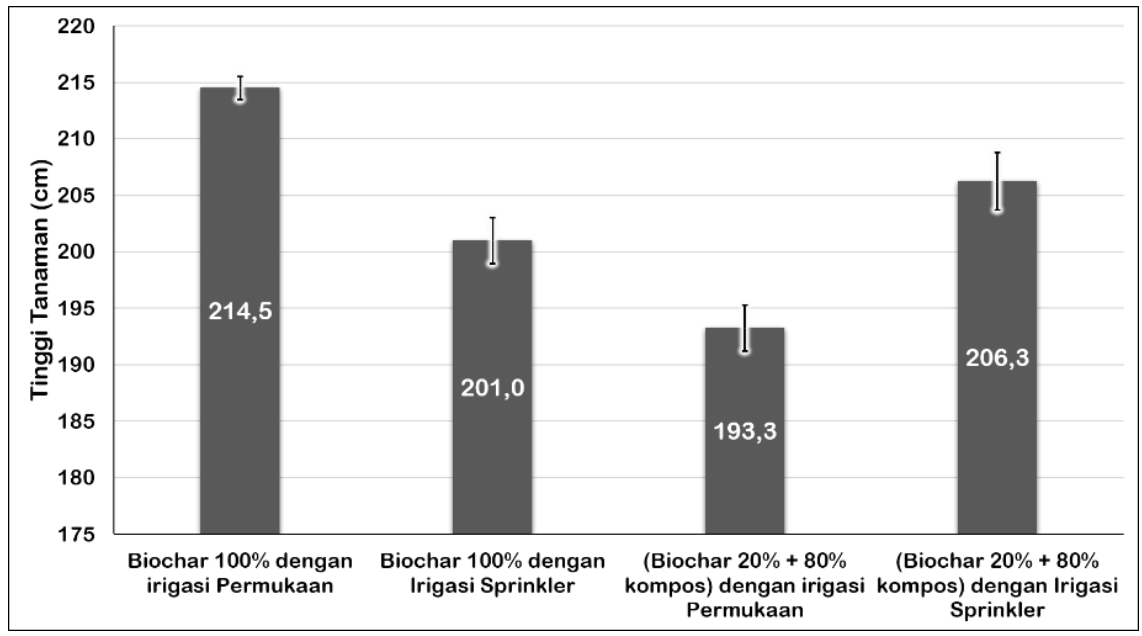

Gambar 4. Tinggi Tanaman Jagung

Secara umum, aplikasi Biochar dapat meningkatkan sifat fisik tanah di bawah pasokan air yang terbatas dan bermanfaat bagi pertumbuhan tanaman di bawah kondisi kering. Namun, harapan bahwa aplikasi $(20 \%$ Biochar $+80 \%$ kompos) dapat menjadikan pemanfaatan air lebih efisien belum tercapai karena menghadapi beberapa kendala, diantaranya distorsi air oleh angin sehingga air menyebar secara tidak merata, suhu tinggi sehingga air diduga lebih banyak yang menguap serta jumlah yang ditahan media dan diserap oleh tanaman menjadi lebih sedikit.

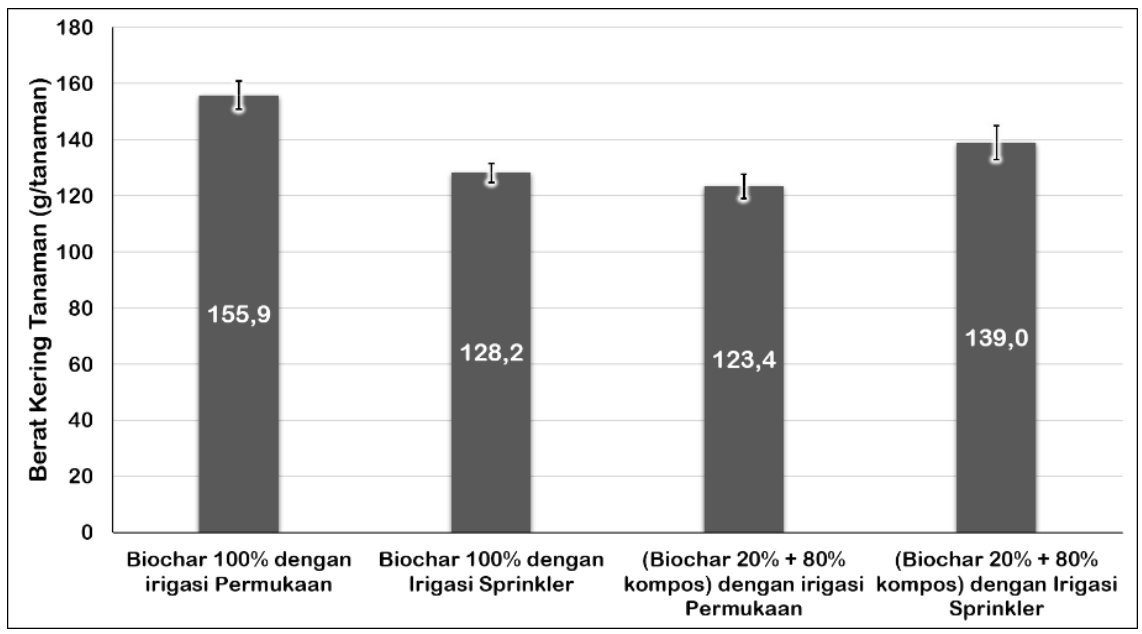

\section{Gambar 5. Berat Kering Tanaman Jagung}

Oleh karenanya, penelitian tentang aplikasi biochar di lahan kering, terutama aplikasi sistem irigasi sprinkler dengan meminimalkan kelemahan irirgasi sprinkler. Penambahan Biochar meningkatkan WHC tanah juga perlu dikaji lebih lanjut, karena WHC tanah menjadi kunci peningkatan produktivitas lahan. Peningkatan WHC tanah di bawah cekaman kekeringan dengan aplikasi Biochar dan/atau kompos akan mendukung proses fotosintesis dan respirasi tanaman serta populasi dan aktivitas mikroorganisme tanah, sehingga KTK meningkat. 


\section{KESIMPULAN}

Aplikasi 100\% Biochar dengan irigasi permukaan berpengaruh nyata terhadap pertumbuhan Tanaman Jagung di Lahan Kering, walaupun pengaruhnya tidak nyata terhadap aplikasi $(20 \%$ Biochar + $80 \%$ Kompos) untuk variable LPR dan Berat Kering Tanaman.

\section{UCAPAN TERIMAKASIH}

Penulis mengucapkan terima kasih kepada Dinas Tanaman Pangan, Hortikultura dan Perkebunan, Pemerintah Kabupaten Situbondo yang telah mendukung kegiatan Fakultas Pertanian Universitas Jember dalam pengembangan lahan kering. Secara khusus, terima kasih disampaikan kepada Ir. Farid Kuntadi Kepala Dinas TPHP Situbondo) dan Dr. Ir. Chendy Tafakresnanto, M.P. (Kepala BPTP Jawa Timur) yang telah memberikan dukungan penuh (dana dan fasilitas) atas terlaksananya penelitian di lahan kering selama dua musim kemarau 2020 dan 2021.

\section{DAFTAR PUSTAKA}

Adnan, A.M., C. Rapar, dan Zubachtirodin. 2010. Deskripsi Variatas Unggul Jagung. Balai Penelitian Tanaman Serealia, Maros.

Ali, M.H. 2010. Fundamentals of Irrigatin and On-Farm Water Management. Volume I. Springer, New York.

Alotaibi, K.D., and J.J. Schoenau, 2019. Addition of Biochar to a Sandy Desert Soil: Effect on Crop Growth, Water Retention and Selected Properties. (Agronomy 2019, 9, 343), pp. 139-152.

Arnon, I. 1992. Agriculture in Dry Lands Principles and Practice. Elsevier, London.

Badan Pusat Statistik. 2021. Analisis Produktivitas Jagung dan Kedelai di Indonesia 2020 (Hasil Survei Ubinan). BPS, Jakarta.

Belit, Y.M., A. Hamzah, R.D.J. Prakoso. 2020. Penggunaan Biochar dan Mol Bonggol Pisang untuk Perbaikan Kualitas Bibit Tanaman Pisang (Musa paradisiaca L). Jurnal IImiah Hijau Cendekia Vol 5(2): 74-81.

Bista, P., R. Ghimire, S. Machado, and L. Pritchett. 2019. Biochar Effects on Soil Properties and Wheat Biomass vary with Fertility Management. Agronomy 9(623): 13-22.
Biswas, R.K. 2015. Drip and Sprinkler Irrigation. NIPA, New Delhi.

Creswell, R. and F.W. Martin. 1998. Dryland Farming: Crops and Techniques for Arid Regions, Echo Technical Note. ECHO, North Ft. Myers, USA.

De-la-Rosa, J.M. 2020. Biochar as Soil Amendment. Impact on Soil Properties and Sustainable Resource Management. MDPI, Tokyo.

Duarte, S.de-J., B. Glaser and C.E.P. Cerri. 2019. Effect of Biochar Particle Size on Physical, Hydrological and Chemical Properties of Loamy and Sandy Tropical Soils. Agronomy 9(343): 193-208.

Hoffmann, W.A. and H. Poorte. 2020. Avoiding Bias in Calculations of Relative Growth Rate. Annals of Botany 80:37-42.

International Institute of Rural Reconstruction. 2002. Managing Dryland Resources, An Extention Manual for Estern and Southern Africa. IIRR, Kenya.

Lichtfouse, E., M. Hamelin, M. Navarrete, and P. Debaeke (Eds). 2011. Sustainable Agriculture. Volume 2. Springer, London.

Magero, C. 2019. Drylands and Climate Change. IUCN, Switzerland.

Magray, M.M., N. Jabeen, M.A. Chattoo, A. Shabir, F.A. Parray, and S.N. Kirmani. 2014. Various problems of dryland agriculture and suggested agrotechniques suitable for dryland vegetable production, Int. Jour. of App. Sc. and Eng. (IJASE) 2(2): 45-57.

Markwell, J., J.C. Osterman and J.L. Mitchell. 1995. Calibration of the Minolta SPAD502 Leaf Chlorophyll Meter. Photosynthesis Research 46: 467-472.

Mulyani, A. 2021. Potensi Lahan Kering untuk Pengembangan Tanaman Pangan, Makalah pada Seminar Nasional Gerakan Tanam di Lahan Perluasan Areal Tanaman Baru (PATB) yang diselenggarakan oleh Kementerian Pertanian pada tanggal 28 September 2021 di Jakarta.

Niemeijer, D., J. Puigdefabregas, R. White, R. Lal, M. Winslow, J. Ziedler, S. Prince, E. Archer, and C. King. 2005. "Dryland Systems" in Hassan, R., R. Scholes, and N. Ash. 2005. Ecosystems and Human Well-being: Current State and Trends, Volume 1. IslandPress, London.

Ritung, S., E. Suryani, D. Subardja, Sukarman, K. Nugroho, Suparto, Hikmatullah, A. Mulyani, C. Tafakresnanto, Y. Sulaeman, R.E. Subandiono, Wahyunto, 
Ponidi, N. Prasodjo, U. Suryana, H. Hidayat, A. Priyono, dan W. Supriatna. 2015. Sumber Daya Lahan Pertanian Indonesia: Luas, Penyebaran, dan Potensi Ketersediaan. IAARD Press, Jakarta.

Suryani, E., E. Sulaeman, S. Bachri, dan W. Adhy. 2020. Laporan Tahunan Balai Besar Sumber Daya Lahan Pertanian 2019 - Inovasi Teknologi Sumberdaya Lahan untuk Pertanian Berkelanjutan. Kementerian Pertanian, Jakarta.

Tsai, C-C and Y-F. Chang. 2019. Carbon Dynamics and Fertility in BiocharAmended Soils with Excessive Compost Application. Agronomy 9(511): 39-54

Umrani, R. and C.K. Jain. 2010. Agroforestry Systems and Practices. Oxford Book Co., India.

Zulfita, D., Surachman dan E. Santoso. 2020. Aplikasi Biochar Sekam Padi dan Pupuk NPK terhadap Serapan N, P, K dan Komponen Hasil Jagung Manis di Lahan Gambut. Jurnal IImiah Hijau Cendekia Vol 5(1): 42-49. 